\title{
Human Security and Refugee Protection after September 11: A Reassessment
}

\author{
Raquel Freitas
}

\begin{abstract}
In the aftermath of the September 11 attacks, the security environment in the Western world has changed considerably. Threat perception and risk management are being reassessed, and the word "security" has acquired an added relevance in the political agenda. This paper addresses a particular derivation of the concept of security, which is human security, from the perspective of refugee protection and human rights of the individual, assessing the advantages and disadvantages, together with the possible uses and misuses of the notion in the post-September 11 context. In particular, it deals with the question of what has changed that could demand greater attention in crafting a human security regime, which may in specific regions be inclusive of some but exclusive of others. It concludes by cautioning against a drift of the concept towards incorporating too many different elements that may be used perversely and against the interests of refugees.
\end{abstract}

\section{Résumé}

À la suite des attentats du 11 septembre, I'environnement en matière de sécurité a consi dérablement changé dans le monde occidental. La perception des menaces et la gestion du risque ont acquis une nouvelle pertinence dans l'agenda politique. Cet article examine un aspect particulier de la notion de sécurité, c.à-d. la sécurité humaine, du point de vue de la protection des réfugiés et des droits de la personne de chaque individu. II tente d'en évaluer les avantages et les inconvénients, aussi bien que les usages et abus possibles dans le contexte de l'après 11 septembre. Plus spécifiquement, il lance une réflexion sur la question de savoir ce qui a changé dans ce nouvel univers qui demanderait plus d'attention afin qu' on puisse façonner un régime de sécurité humaine qui, dans certaines régions, inclurait certains groupes et en exclurait d'autres. L'article conclut avec une mise en garde contre une dérive de la notion pour inclure trop d'éléments disparates qui pourraient être utilisés d'une manière perverse et contre les intérêts des réfugiés.

$Q^{i}$ ince the end of the Cold War, and in particular in the mid-1990s, after a succession of violent crises that resulted in the death of thousands of civilians, the concept of human security came to light with a strong moral stance and a project of responsabilization of the international community for the fate of the victims of conflicts, as well as for a host of other problems that degraded thehuman condition. Already in the 1970s there were significant attempts to create better standards of living worldwide through the project of the New International Economic Order (NIEO), but these were eventually replaced in the 1980s by neo-liberal economics. ${ }^{1}$ The concept of human security emerged in the 1990s as a renewed attempt to increase the well-being of the individual at all levels, taking the emphasis away from the traditional defence-oriented, statist view of security.

The post-September 11 environment raises new challenges in the international system, regarding not only the traditional concept of security, but al so the construction of the concept of human security. This article is interested in understanding how the concept of human security shapes the panorama of refugee protection and what has changed in this new world that could call for greater attention in crafting a human security regime. It is argued that September 11 emphasized a number of existing ambivalences and 
a mixture of antagonistic forces of closure and openness: a combination of the post-Cold War trend of universalism and world politics with a renewed state-centrism on the one hand, and an apparent increasing incompatibility between human rights and internal security on the other hand. ${ }^{2}$

The resurgence of the notion of "internal security" reinforces its already problematic relation with "human security." The random development of the latter concept may leave it open to different interpretations, which derive too much from the intended goals of most of its promoters. Depending on its positive or negative framing, "human security" in the post-September 11 environment may reverse the present tendency to associate anti-terrorism policies with diminishing refugee protection, thus increasing concern for refugees, or it may contribute to consolidating the forces of closure and emphasize the dynamics of inclusion/exclusion.

The article proceeds first with a critical overview of different approaches to security, without attempting to provide one definition, and focusing on the dimension of the concept that impinges on theissue of refugee protection and on how it can be framed. It then provides an account of the role of the concept of human security in the international system and of how refugee protection is conceived in the same system, before and after September 11. Finally it concentrates on the specific impact of the terrorist attacks on refugee protection and the actual and potential role of the concept of human security in such context.

\section{The Emergence of the Concept of $\mathrm{H}$ uman Security}

Multiplicity of Approaches

The concept of security originated in foreign policy. I nitially it concerned protection of national territory and population, the main attributes of the state. In some countries it evolved into a foreign policy option that overcame the militaristic sense of security based on an anarchic international system, and took on a humanitarian dimension. ${ }^{3}$ In other countries the reconceptualization was part of comprehensive defence reviews that shifted security to an internal level as a result of generalized internal violence. ${ }^{4}$

The first significant references to "human security" appear in the early 1990s, at the origins of the Common Security Forum (CSF), an international research centre, whose aim is to explore economic, political, and other conceptions of security and which promotes dialogue among academics, governments, and institutions doing research on global security issues. ${ }^{5}$ In addition, several other institutions actively promote the concept; these include the Human Security Network; Commission on Global Governance; the Global Environmental Changeand
Human Security Project; and the Commission on Human Security.

Several initiatives at the level of international organizations such as NATO, the W orld Bank, and in particular the UN, have also contributed to bringing about and promoting the concept of human security. N amely, the UN Secretary-General's Agenda for Peace focused on the impact of the end of the Cold War on international security and promoted an integrative approach to human security. ${ }^{6}$ The most significant UN initiative so far has been the 1993 UNDP H uman D evelopment Report, 7 proposing a concept of human security based on the pillars of freedom from fear and freedom from want. The threats identified were grouped into seven main categories: economic, food, health, environment, personal, community, and political.

"H uman security," as has been framed by these actors and institutions, entails the logic of universal rights to minimum standards of life, placing the individual instead of thestate as the referent object of security and at thecentre of concern not only regarding physical security but also regarding economic, social, environmental, and human rights security. This extended framework has been emphasized in particular in the context of the U nited $\mathrm{N}$ ations $\mathrm{H}$ igh Commissioner for Refugees (UNHCR), whose populations of concern have been increasingly deprived of the minimum standards of security in situations of conflict and of mass displacement. ${ }^{8}$ This has led the former $\mathrm{H}$ igh Commissioner, Sadako Ogata, to endorse the concept of human security, with strong support from the government of Japan. In her own words: "R efugee protection is a set of legal instruments, operational activities and material contributions that can restore a sense of security in people whom flight has deprived of everything. ..." ${ }^{9}$ This is in line with the integrative conception of human security and the promotion of a link from relief to development in refugee protection and conflict situations. In the context of refugee protection, human security becomes particularly useful for advocacy purposes since it overcomes the limits set by a strict interpretation of the UNHCR's mandate as it integrates all categories of people, whether formally refugees or not. However, the use of the concept is riddled with ambivalence deriving from the need to combine human rights concerns with state interests. ${ }^{10}$

Universalism and indivisibility of "human security" are two of the main characteristics of the concept. The ambition of universalism aims at going beyond the idea of state-centred world politics where each state is responsible for the security of its territory and population, by placing the responsibility for all individuals at the level of the international community, and coordinating the efforts and activities at the level of different types of actors. ${ }^{11}$ The 
importance of the individual as holder of universal rights, among them that of security, isillustrated by the increasing number of legal rules directed at individuals rather than states. ${ }^{12}$

In the same logic of universalism and indivisibility, some approaches to "human security" develop conceptions that aspire to being general models, more or less applicable to any society in the world. Bajpai suggests an audit of human security in theline of the human development audit carried out annually by UNDP, which would assess the conditions of safety and freedom of individuals measured by direct and indirect threats to security and by the capacity of the decision-making structures (i.e., not only states) to deal with such threats. ${ }^{13}$

This conception is rooted in theidea that human security is indeed a universal and objective quality of social life, where the different components are integrated and indivisible. Although in ideological terms very valuable, there are problems with this approach in that it would need a very clearly delimited concept definition and also the assignment of structures responsiblefor and capable of enforcing such human security standards and which could be made accountable for such a role. In Bajpai's framework responsibility is attributed to state, sub-state and non-state actor levels and therefore removed from the sole state-centred responsibility, which has the effect of dispersing accountability. Further, it may be used to legitimize declaring certain groups as having acceptable levels of "human security," when not all indicators are considered or at the same level, since such measurement would always be focused on a number of specific items. This would in turn legitimize increasingly restrictive refugee policies and take even more responsibility away from the international community of states. ${ }^{14}$

The ambition of universalism has al so been contested by authors who argue that the concept of human security is not universal but rather a W estern construction ${ }^{15}$ and that appropriating thenation-state-based security model for use in regions with a different history and culture may add to the problems instead of solving them. ${ }^{16}$ Indeed, many dimensions that "human security" encompasses are cultural and context-dependent. Thus, as Lipschutz puts it, security is an "intersubjective phenomenon" rather than an objective condition, and different regions construct it differently. ${ }^{17}$

Other criticisms of the human security concept, in particular the UNDP version, argue that it is too vague, not objectively measurable and too woolly, too encompassing and lacking specification. ${ }^{18}$ The concept of human security is still in evolution and not only academics but also policy makers and activists should consider carefully the nature of their positions and possible implications when promoting their ideas. ${ }^{19}$

\section{Dissecting human security}

There is an intense debate regarding the nature of the concept of security, ${ }^{20}$ how it should be conceptualized, and in particular regarding the advantages and disadvantages of widening it. ${ }^{21}$

W aever draws attention to the "securitizing" dimension of the concept of security and to the fact that broadening should not be made without considering the political implications and the historical connotations that the concept of security bears. For him the referent object is still thestate, and ". . . addressing an issue in security terms still evokes an image of threat-defense, allocating to the statean important role in addressing it. . ."22 which, according to the author, is not always an improvement.

Conceiving security as a social construction, the constructivist perspective posits the existence of a normative dilemma in securitizing immigration and refugee issues. According to H uysmans, by taking security away from the state and to the societal, private, or individual level we run the risk of delegitimizing not only the state but also of legitimizing nationalistic and xenophobic reactions. ${ }^{23}$

Lipschutz demonstrates how important the state-centric differentiation between the self and the enemy is for security as a discourse and points to the post-Cold W ar difficulty of finding new enemies. ${ }^{24}$ In the present context, one should caution that just as a new significant enemy has been found - "terrorism" - so al so the contestablenature of what a terrorist is may induce confusion with refugees and lead to their construction as enemies or at least elements to be excluded from the newly threatened and insecure societies.

The important elements in assessing human security are not just the concept in itself, but how and in which context it is framed, ${ }^{25}$ and which other concepts are associated with it. At the current stage of loose definition of "human security," the attached concepts are the determining factors in providing the framing and the referent object. I suggest that depending on the framing process and on the ideological association with other concepts and referent objects, "human security" will take on a positive or a negative value as far as human rights values and refugee protection aspects are concerned.

In the literature, the concept of human security oscillates from a focus on states ${ }^{26}$ as referent object, to a focus on individuals ${ }^{27}$ and on society. ${ }^{28}$ Focusing on the framing ideologies, I would here propose a differentiation within the concept of human security itself, i.e., that of human security and human insecurity. I suggest that the intended interpretation of "human security" asan ideological project 
is associated with human rights and world governance conceptions, while "human insecurity" is associated with internal security and state-centric conceptions of theinternational system.

In the context of refugee protection different ideological projects that use the term "human security" may have distinct referent objects, which define which security is at stake: in the case of human insecurity the referent object is the citizen of a particular community (citizen security from external threats), while in the case of human security it is the refugee (refugee security). These distinctions are intended to provide analytical clarity and help delimit the boundaries of what is conceived as human security.

$H$ uman security and human insecurity. The main element in this distinction is the qualification of positive and negative security. The broadened concept of security, in particular the human security version, entails a positive conception of security in the sense of an absence of threats to the well-being and quality of life, whereas other conceptions of security rely much more on the very construction of those threats. This negative dimension I will call human insecurity. Eriksson develops a theory of threat politics, which includes two main dimensions: framing and societal salience. Both threats and risks are seen as social constructions and the politics of framing are seen as an important instrument of power. ${ }^{29}$

$\mathrm{H}$ ere we conceive of human security and human insecurity in opposing terms in order to highlight the essentially contradictory terms in which the concept "human security" can be framed. Human security is then associated in normative terms with efforts to promote global governance and universal well-being without the intention of constructing threats (insecurity), but of promoting their absence (security), namely through the association with human rights. On the other hand, "human insecurity" is more closely associated with the promotion of internal security in exclusionary terms.

A. "H uman security" and human rights. The low enforcement of first-generation human rights in the world has to some extent kept the refugee regime going, despite increasing reluctance of Western states to admit refugees and a selective application of humanitarian funds and resources which has been to a great extent dependent on the media impact and Western interests in specific emergencies. Regarding second-generation human rights, the situation has been even worse, with states unwilling to provide funds for reconstruction of societies, or for the promotion of economic and social conditions for development.

"H uman security" appears as a way to push forward the two generations of rights and link them with a strong agenda, namely the proposal of the creation of an Economic
Security Council. ${ }^{30}$ The problem, as pointed out by some observers, is that sometimes it is difficult to establish a distinction between "securitarian" ideology and human rights since often the discourses are not very far from each other, often sharing the same vision of what is "insecure," and only differing regarding the proposed solutions. H ence the need for due contextualization of alternative discourses such as critical security and human rights in relation to the dominant one. ${ }^{31}$ Further, moving the discourse of refugee protection from the real $m$ of human rights to that of security risks not only operates a switch in perspectives and wordings, but also changes the focus from the refugees to the receiving state. ${ }^{32}$

B. "Human insecurity" and internal security. There are two types of "human insecurity" that may affect refugee protection: the fear of terrorism and the fear of "invasions" of migrants who enter illegally and abuse the asylum system. ${ }^{33}$ As it is difficult to establish whom the terrorists are, an artificial "inside/outside" or "inclusion/exclusion" framework ${ }^{34}$ is established that impacts particularly on refugees and asylum seekers.

The construction of security entailsa construction of risk perceptions, which also depends on the different social groups: one group in particular, theindividual istic, is likely to see increasing refugeenumbers as a threat, depending on their positive or negative impact on economic growth. ${ }^{35}$ In this case, people, or the polity, feel threatened in their "well-being" by the presence of so many immigrants and by the uncontrollable nature of their arrival and presence in the territory.

H uman security and citizen security. Instead of displacing the referent object from state security to human security, a "human insecurity" framing turns the citizen into the referent object, 36 in "an attempt to generate a democratic and participatory response to the thorny issue of protection and repression." ${ }^{37}$ Although citizen security and logics of public order and safety refer to something different than common approaches to human security, it is a fact that such exclusionary logics can easily appropriate the concept, due to a perceived absence of state capacity to uphold public order. That is to some extent related to a certain feeling of impotence of Western states regarding their capacity to determine who is admitted into the country, which increases the likelihood of restrictions on those that resort to the asylum system: "In a world of risk this is an area where states perhaps believe they can, either individually or collectively, continue to be assertive." 38

According to $\mathrm{H}$ arvey one should look at the constitutive principles of democratic polities to understand the potential for contradiction between what we call citizen security and the security of "others": "The treatment of asylum- 
seekers brings to the fore a tension between notions of democratic citizenship and 'borderless' strains of liberalism that are anchored in the idea that rights attach to the person." 39 Even if these two are not in themselves irreconcilable, the risk is that they areframed as such, in particular when individual welfare and the presence of refugees are perceived as incompatible, as is the worrying case in many countries in Europe and in Australia. ${ }^{40}$

$H$ uman security and refugee security. $H$ ere lies the main problem with the referent object: whose "refugee security"? Is it security from refugees, or is it security of refugees? The debate persists about whether to consider refugee movements as "human security threats."

Although Suhrke does not discard the security paradigm as inappropriate for migration, she cautions against a hasty classification of population displacements as a human security threat. ${ }^{41}$ Zimmermann enumerates a number of categories of threats ". . . posed by migration to a stable and productive world order": spill-over of refugee crises; severe persecution of minorities; destabilization of states; failed states; technological sources such as landmines; root causes. ${ }^{42}$ Also W einer has identified five broad categories of ways in which migratory movements can threaten security: when refugees and migrants are working against the regime of their home country; when they pose a risk to their host country; when immigrants are seen as a cultural threat; when they are perceived as a social or economic threat; when the host country uses immigrants as instruments to threaten the country of origin. ${ }^{43}$

In this case the referent object of security is clearly the host society. But is it a human security threat? Treated in the sense of a threat, it is rather a societal ${ }^{44}$ or international security threat, or human insecurity. Treated in the sense of ensuring protection to those displaced it ishuman security. $\mathrm{H}$ ereis the ambivalence of framing possi bilities and contexts.

Whitaker underlines the political significance of the scare of refugee tides in the immediate post-Cold $W$ ar context ". . . in a world where the 'refugee' has been under reconstruction as an object of popular anxiety and aversion." ${ }^{45}$ Indeed, the major problem is when one speaks of refugees in the context of "human security threats," ${ }^{46}$ which leads to the idea that something else is threatened. In fact what causes the population movement is a lack of human security (if the referent object is the migrants and not others), but the expression may end up being interpreted in the sense that we here conceive as "human insecurity," i.e., that the movements themsel ves are threats. In the most general formulation, they can constitute human security threats if their massive presence destabilizes the host society, and even the Security Council designates such movements as threats to international peace and stability.

\section{The Conceptualization of "H uman Security" and of Refugee Protection in the Contemporary International System}

The A mbivalent International System

For analytical purposes, the post-Cold War world can be characterized by the coexistence of two different types of structures: a state-centric one based on the Westphalian conceptions of states as autonomous and independent territorial units, and a world system based on post-statist conceptions of world governance and an emphasis on the individual as the central unit of concern. Despite considerable progress in establishing the rudiments of an international polity through the development of international institutions, ${ }^{47}$ the international system is increasingly characterized by a strong degree of uncertainty and instability. ${ }^{48}$

While this has led to a tendency for the erosion of sovereignty, ${ }^{49}$ it has at the same time contributed to a less clear notion of where responsibilities liefor issues that have been put on theinternational agenda. Also an increasing number of non-state actors with significant influence in the international system contribute to this disaggregation..$^{50}$ One consequence of removing responsibilities for protection away from a state-centric framework may be that no entity is held accountableany more. This "upgrading" of humanitarian rights to the "cosmopolitan" sphere ${ }^{51}$ has al ready led to a significant degree of carelessness by states - which in the end retain most of the funding power - regarding the protection of refugees, with the argument that they are protected in their territories by some international institution. ${ }^{52}$ If the state has its responsibilities removed, and on top of that it hasa chance to appropriate thehuman security discourse to security issues that suit internal political goals, then refugee protection is worse off. In this context, the concept of human security falls prey to the dominating tendencies in the international system, which is characterized by the coexistence of contradictory forces ${ }^{53}$ that belong to different framing processes of the world and international politics.

At the sametime, the refugee protection regime has been increasingly undermined by state policies that promote closure rather than openness and by lack of political will to keep their commitment to the 1951 Convention on the Status of Refugees. There is a return to the state-centric framework as a reaction to globalization and to the effect of mass migration, which has been an ongoing trend and "... has engendered a growing sense of exposure or vulnerability to what had previousl y seemed distant and inconsequential." 54 It has also resulted in ". . . a more tightly regulated public space for the marginalized." 55 This trend, which is underpinned by the notion of internal security, has since September 11 been emphasized by the reaction to terrorism. 
Actors and Institutional Aspects

As politics is about choices and priorities there has been a need to prioritize certain pressing human rights concerns and bring them into theinternational agenda with a renewed emphasis. This was done by attempting to bridge the needs and problems of the poor and destitute with the interests of states and thus the concept of human security joined the normative with the pragmatic approach.

Several UN officials have been trying to promotea vision of human security based on human rights norms, in particular second-generation rights, which were not cherished by some countries, including the U.S. ${ }^{56}$ Thus a broad and integrative concept of human security was developed. NGO sand civil society in general have al so had a prominent role in helping the UN disseminate the concept of human security, in particular by promoting research on theissue. ${ }^{57}$ Despitethemoral motivations of these actors, it is clear that many of these approaches were stimulated both by institutional ambitions of promoting grand visions of new concepts ${ }^{58}$ and by the need to attract funds and resources for new issues. ${ }^{59}$

A number of countries have also significantly contributed to the emergence of thenew concept; among them the most prominent were Norway, Canada, and Japan. Other countries, such as South Africa, have developed their own notions of human security. H owever, among the countries that actively promoted human security thereare significant divergences. WhileSouth Africa has a clear internal version of human security, Norway, Canada, and Japan, in their program of "middle-power foreign policy," are more predisposed towards the foreign policy dimension of the concept. But even among the latter thereare distinctions, since Canada emphasizes a more humanitarian type of human security, based on first-generation human rights, while Japan emphasizes more the economic dimension, i.e., second-generation human rights. ${ }^{60}$

According to Baldwin, most of the efforts to redefine security

. . . are more concerned with redefining the policy agendas of nation-states than with the concept of security itself. Such proposals are usually buttressed with a mixture of normative arguments about which values of which people or groups of people should be protected, and empirical arguments as to the nature and magnitude of threats to those values. ${ }^{61}$

H owever, the extent of security review and revision since the 1990s has varied tremendously. ${ }^{62}$ While in the United States and Western Europe not much has changed, the so-called "middle powers" have operated more profound reviews and policy revisions. Also many former Soviet-bloc states and democratizing developing countries, including South Africa, have been obliged to fundamentally re-examine their security assumptions.

The latter has undergoneone of the most comprehensive defenceand security reviews in the devel oping world, much of which was a result of the military's ambition for task expansion. ${ }^{63}$ Securitizing an issue can bea way of legitimizing theappropriation and manipulation of new issue-areas by the power holders. ${ }^{64} \mathrm{Abiri}$ analyzes the cases of securitization of cross-border migration in Sweden and Malawi and concludes that in both cases it was used as a channel for political purposes: "In Malawi, the securitization is carried out as a way to consolidate democratic rule, while in Sweden it is used as a way to recapture faith in politics." 65

Indeed, political and institutional aspects are very important in explaining the way the concept of human security is framed and used. In some cases it becomes clear that there are significant institutional divisions within the governments of states, and it is expected that such tension occurs between ministries of foreign affairs with foreign policies that areactive in human rights, and in particular in the promotion of human security, and ministries of internal affairs that are concerned about the protection of the citizens. Evidence in Canada shows that there isn't much inter-ministerial agreement regarding the definition and use of human security. ${ }^{66}$

A final issue of concern in the present international system, which requires caution and a clear delimitation of the concept of "human security" by activists as well as academicsand decision makers, is therisein right-wing and even extremist anti-immigration parties that use any kind of rhetoric to pursue their political purposes.

\section{The Impact of the Terrorist Attacks on "H uman Security" and Refugee Protection}

The September 11 attacks were an overwhel ming event not only for the magnitude of the crime and appalling nature of the act and of its planning, but also for its symbolic nature. The events led not only observers but also decision makers and politicians to reconsider the state of world politics. The attacks led to an abrupt and unprecedented state of emergency, where exceptional security measures were enforced, which had immediate impact on refugee policy and legislation - although in some countries more than others - and may have an impact on how refugees are perceived in the different countries regarding security constraints, not only in the short but also in the long run.

$M$ any countries introduced restrictive measures, including front-end security screening for all asylum-seekers immediately upon their arrival at land-borders and airports. ${ }^{67}$ The U.S. initially ground to a halt and then reduced its 
resettlement program drastically, ${ }^{68}$ creating an enormous backlog and risking undermining the whole refugee resettlement structure. ${ }^{69}$ After the attacks on the U.S., the government adopted new and unprecedented immigration legislation in an expedited manner on September $26,{ }^{70}$ and soon after tried to impose specific measures in the framework of counterterrorist co-operation with the EU, ${ }^{71}$ and also tried to impose the "perimeter continental security" on Canada. ${ }^{72}$ This reflects a worrying policy of internationalization of the "state of exception."73

In a very interesting critique of the expansive definition of security, Jayasuriya claims that the new debate extends U.S. "law and order" to thetransnational arena. In her own words, these developments ". . . reinforce the emergence of a new form of the regulatory state that has the 'securitization of civil society' as a key governance strategy. In fact, it is possible to see in some aspects of these developments the 'internationalization of the state of exception' that $\mathrm{Neu}$ mann so brilliantly analyzed."74

Whitaker also points out the degree of institutionalization of international co-operation promoted by the U.S. to combat terrorism, which "... rests upon certain consensual definitions of the nature of the threat." 75 Terrorism is a contestable concept and a clear definition is also hard to come by. ${ }^{76}$ Further, as Bigo points out, there is a danger of overexpanding the concept of "terrorist" to the ridiculous extent of including youth demonstrators in the samelot as Bin Laden. The same observer criticizes the justification of security measures aimed at limiting immigration and asylum on the grounds of the insecurity situation created by the attacks and calls for a study of the impact of these new measures on a range of issues. ${ }^{77}$

In Germany, advocacy groups reported that efforts to include adequate human rights safeguards for refugees in proposed asylum legislation suffered a serious setback in the aftermath of the September 11 attacks with many viewing the new legislation as a necessary measure to strengthen national security. ${ }^{78}$ In Greece, Afghan refugees who arrived after the September 11 attacks received a hostile reception as the government refused to allow them to apply for asylum, violating its obligations under the Refugee Convention. In Hungary, all Afghan asylum seekers were transferred from open reception centres to facilities with heightened security measures.

One of the immediate effects was a reappearance of the word "security," used in very narrow terms. ${ }^{79}$ The main issues of concern are the restrictiveness of how asylum law and entry regulations are applied, but in particular the legitimation of situations of detention at borders and significant increases in deportations. ${ }^{80}$ These, as well as other measures that go well beyond counterterrorism, have been justified with the need to maintain internal security, and thereis very little concern for clarifying that refugees should not be seen as threats to such security. H owever, in many countries, not only in the U.S. but also Europe and Australia, ethnic and minority groups such as Afghan refugees and Muslim immigrants were termed "terrorists". ${ }^{81}$

Uncertainty of the whole counterterrorist process leads to what Whitaker calls a ". . . definitional stew of disparate elements," where refugee claimants submitting to security screening for terrorist connections face a real-life lottery, with uncertain rules and unpredictable results. ${ }^{82}$ While the increased use of confidential information without regard for data protection requirements is applied with the justification of internal security against terrorism, it may well be used against the interests of legitimate refugees. ${ }^{83}$

After the attackson the Twin T owers, civil-rights organizations immediately called attention to the idea that the fight against terrorism should not serveto justify repression and argued for advancing human development as one of the main principles to pursue in response, including the concepts used by UNDP for expanding human security, such as freedom from fear and freed om from want. ${ }^{84} \mathrm{~T}$ hus, not all outcomes of policy changes have been bad, and there seems to be a new impetus for promoting economic development and sustainability, in other words, a sufficient degree of "human security" that will at least prevent certain parts of the world from being so desperate. The future will tell whether thepresent commitments will last and translate into effective policies, but the international community should at least make sure that they don't serve to legitimize exclusionary policies of other type. Further, theperceptions of newcomers, namely refugees, as a threat is not merely a post-September 11 event. Already before that, such perception was widespread. ${ }^{85}$

One of the most serious problems of internal security against terrorism that affects refugee protection is that asylum is political, and the acceptability or not of particular migrants is dependent on the relation of the host country with the country of origin, as there is al ways the fear that the refugee may use the host country as a base for eventual terrorist activities. ${ }^{86}$ There is also the problem that the country of origin may havea distorted notion of "terrorist," which makes it politically difficult for the host country to accept those who duly should receive protection from persecution for having wanted to restore democratic values in the country of origin.

In sum, the terrorist attacks emphasized the contradiction between internal security and human rightsand clearly made refugee security more difficult. These contradictions were present at the internal level, as exemplified in the Canadian government's way of deal ing with theissue: while 
in internal affairs the reaction was to reinsure the security of the citizens, in the foreign office there was more concern to emphasize the need to respect the rights of the refugees.

As pointed out above, the terrorist attacks but also, I would argue, an ongoing trend of reaction to gl obalization have resulted in a generalized resurgence of nationalism, and thisisconfirmed by the shift in thestrategy of theglobal civil society project that is redirecting attention towards new emphasis on the state as central element of international decision making. ${ }^{87}$

\section{Conclusion}

Because the concept of human security is at this stage so loose and all-encompassing, it can easily turn into a subtle instrument for justifying restrictions and underlining the sense of community and internal security, in particular when themotivation behind such change has themagnitude of the September 11 events. Terrorism strengthens the position of those actors who defend a version of negative framing of human security through the construction of threats to internal security and of "human insecurity" notions.

However, in the post-September 11 world one has to consider not only the immediate and direct effects of the attacks on the Twin T owers, but also the previous trend of restrictionism regarding acceptance of refugees and migrants. It is too simplistic to focus exclusively on theimpact of a singleoverwhelming event al though it has significantly contributed to reinforcing conditions that al ready preceded it. Indeed, counterterrorism framings are to a large extent based on the opposition between refugees and citizens as referent object of security. Theevents of September 11 have a high likelihood of further biasing opinions towards the criminalization of foreigners, in particular those coming from specific parts of the world and with a background of political activism. This is to add to the general attitude of criminalization of those asylum seekers who are smuggled into a country in search of protection.

The problem with the human security approach is that many of those who promoteit tend to plunge too easily into a world politics or cosmopolitan approach, forgetting that the state still has a fundamental role in international relations. Here, the importance of the agent who is trying to bring about a change in the international system is underlined: thestate is theidentifiable criterion by which to judge whether we are talking about human security or just internal security, as its institutions have enormous framing power. Thus, when defining theconcept of human security, the ideological motivations of the framing agent should be madeexplicit and delimited. Sinceit is assumed that human security as a concept and a human rights program may work well if it is clearly defined and formulated within a world politics framework, the current reversal towards the state as the central element in international relations calls for careful reflection on the concept's potential and consequences in particular asfar as refugeeprotection is concerned.

\section{Notes}

1. Chris Brown, "The N ormative Framework of Post-Cold War International Relations." In TheN ew Agenda for I nternational Relations, ed. Stephanie Lawson (Cambridge: Polity Press, 2002).

2. Policies relating to human rights and human security are predominantly located in world governance logics of decision making, while those related to terrorism and internal security are predominantly located in state-centric logics. See Sandra Lavenex, TheEuropeanization of RefugeePolicies: Between $\mathrm{H} \mathrm{u}$ man Rights and Internal Security. Doctoral dissertation. (Florence: EUI, 1999).

3. This is the case of the so-called "middle powers", such as Canada, N orway, and Japan.

4. South Africa is one of the best and most studied examples. See Gavin Cawthra, From "Total Strategy" to "H uman Security": TheM aking of South Africa's D efencePolicy 1990-1998. W orking Papers, 8. (Copenhagen: COPRI, 1999).

5. Sarah Edsen, Human Security: An Extended and Annotated International Bibliography (Cambridge: King's College, University of Cambridge, 2001).

6. See full text online: <http://www.un.org/Docs/SG/agpeace. $\mathrm{html}>$.

7. See full text online: <http://hdr.undp.org/reports/global/ 1993/en/default.cfm>.

8. Thedeterioration of the refugee protection regime in terms of decreasing willingness of states to receive refugees, together with theincreasing numbers of forced migrants, led to policies that tend to keep these populations in need closer to - if not inside- their country of origin. This means they are physically much morevulnerableto thecollateral effects of wars. Thelack of political will to address these situations has led the High Commissioner to call for efforts to ensure the physical security of the refugees and other displaced and even non-displaced populations.

9. Sadako Ogata, "Human Security: A Refugee Perspective." M inisterial M eeting on H uman Security I ssues of the "Lysoen Process" Group of Governments, May 1999: 5.

10. Anne Hammerstad, "UN HCR, Refugee Protection and State Security," Security Dialogue 31, no. 4 (2000): 391-403.

11. GeorgeM aclean, "Instituting and Projecting H uman Security: A Canadian Perspective," Australian Journal of International Affairs 54, no. 3 (2000): 269-276.

12. G.H. Fox, "New Approaches to International Human Rights: The Sovereign State Revisited." In State Sovereignty Change and Persistence in International Relations, ed. Sohail H. Hashmi, (University Park: Pennsylvania State University Press, 1997), 105-30. 
13. Kanti Bajpai, Human Security: Concept and M easurement. Occasional Paper, 19. (New Delhi: Kroc Institute, 2000).

14. See B. Frelick, "Secure and Durable Asylum: Article 34 of the Refugee Convention," World Refugee Survey 2001 (2001): 42-55.

15. See Kinhide M ushakoji, "Human Security as an Integrative Concept for the UN," Prime 2 (94): 40-52.

16. Ellen Lammers, Refugees, Gender and H uman Security: A Theoretical Introduction and Annotated Bibliography. (U trecht: International Books, 1999): 49.

17. Ronnie D. Lipschutz, "N egotiating the Boundaries of Difference and Security at M illennium's End." In Security, ed. Ronnie D. Lipschutz (New York: Columbia University Press, 1995), 213.

18. Heather Owens and Barbara Arneil, "The Human Security Paradigm Shift: A New Lens on Canadian Foreign Policy?" Canadian Foreign Policy 7 (99): 1-12.

19. On the debate over the political role of security analysts, see Ole Waever, "Securitizing Sectors? Reply to Eriksson," Cooperation and Conflict 34, no. 3 (99): 334-40; Johan Eriksson, "Observers of Advocates? On the Political Role of Security Analysts," Cooperation and Conflict 34, no. 3 (99): 311-30; Kjell Goldmann, "Issues, Not Labels, Please!: Reply to Eriksson," Cooperation and Conflict 34, no. 3 (99): 331-33.; M ichael C. Williams, "The Practices of Security - Critical Contributions: Reply to Eriksson, Cooperation and Conflict 34, no. 3 (99): 341-44; see also Jef Huysmans, "Dire et écrire la sécurité: ledilemmenormatif des études de sécurité," Cultures et Conflits 31-32, no. Automne-hiver (98): 177-202.; K.M. Fierke, "M eaning, M ethod and Practice: Assessing the Changing Security Agenda," in The N ew Agenda for International Relations, ed. Stephanie Lawson (Cambridge: Polity Press, 2002).

20. One of the most commonly agreed features of the concept is its contested nature. See Barry Buzan, People, States and Fear: An Agenda for International Security Studies in the Post-Cold War Era, 2nd ed. (N ew York: H arvester Wheatsheaf, 1991).; Richard Little, "Ideology and Change," in Change and the Study of International Relations: The Evaded Dimension, eds. Barry Buzan and Barry Jones, (London: Pinter, 1981); Arnold Wolfers, "'National Security' as an Ambiguous Symbol," Political Science Quarterly 67, no. 4 (52), 481-502. For an argument that downplays such contested nature of theconcept and emphasizes the practical conditionsfor its disregard, seeD avid A. Baldwin, "TheConcept of Security," Review of International Studies 23 (1997): 5-26.

21. See Eriksson, Johan, op. cit.; Barry Buzan, Ole Waever, and Jaap DeWilde, Security: A N ew Framework for Analysis (Boulder: Lynne Rienner, 1998), 2-5.

22. Ole Waever, "Securitization and Desecuritization." In On Security, ed. RonnieD. Lipschutz, (N ew York: Columbia University Press, 1995), 47. This author defines security problems as "... developments that threaten the sovereignty or independence of a statein a particularly rapid or dramatic fashion, and deprive it of the capacity to manage by itself." I bid., 54.
23. Jef Huysmans, op. cit.

24. Ronnie D. Lipschutz, op. cit.

25. Johan Eriksson, ed., Threat Politics: $N$ ew Perspectives on Security, Risk and Crisis M anagement (Aldershot: Ashgate, 2001), 6 , defines a frame as “... the power struggle for a shared narrative, in our case about what counts as 'threat', 'risk' and similar negative concerns." In this essay we will consider also positive concerns as a useful tool to distinguish different possible types of framing of "human security."

26. Traditional conceptions of security.

27. Anna M. Florini and P.J. Simmons, "North America." In The New Security Agenda: A Global Survey, ed.. Paul B. Stares (Tokyo: Japan Center for International Exchange, 1998); David T. Graham and N ana K. Poku, eds., M igration, Globalisation and H uman Security (London: Routledge, 2000); N ana K. Poku, N eil Renwick, and John Glenn, "H uman Security in a Globalising World." In M igration, Globalisation and Human Security, ed. David T. Graham and Nana K. Poku (London: Routledge, 2000).

28. SeetheCopenhagen School, namely O leW aever, Barry Buzan, M orten Kelstrup, and Pierre Lemaitre, I dentity, M igration and the N ew Security Agenda in Europe (London: Pinter, 1993).; and sociological approaches with a focus on identity, M artin Shaw, "There Is No Such Thing as Society: Beyond Individualism and Statism in International Security Studies," Review of International Studies 19 (93): 159-75: 160.

29. Johan Eriksson, op. cit.

30. George Maclean, op. cit.

31. Jef Huysmans, op. cit.

32. Elisabeth Abiri, "M igration and Security from a N orth-South Perspective: Sweden and M alawi." In M igration, Globalisation and H uman Security, eds David T. Graham and N ana K. Poku (London: Routledge, 2000), 72.

33. "Fear of mass migration, for example, and the social and political instabilities that it can engender, characterizes the political relations of the U nited States and M exico, Franceand Northern Africa, and Germany and its Eastern neighbors." Peter J. Katzenstein, "Conclusion: National Security in a Changing World." In The Culture of N ational Security N orms and Identity in World Politics, ed. Peter J. Katzenstein ( $\mathrm{N}$ ew York: Columbia University Press, 1996), 524.

34. For the problematization of the problems of inclusion and exclusion in political theory and also in the context of immigration and refugee movements, see R B J Walker, O neW orld, $M$ any W orlds: Struggles for a Just W orld Peace (Boulder, Colo.: Lynne Rienner, 1988); R B J Walker, Inside-Outside International Relations as Political Theory. Cambridge Studies in International Relations, 24. (Cambridge: Cambridge U niversity Press, 1993); M. Dillon, "Sovereignty and Governmentality: From the Problematics of the 'N ew W orld Order' to the Ethical Problematic of the World Order," Alternatives 20 (95): 323-68.

35. UIf Bjereld, "Cultural Theory, Risk Perceptions among Political Elites and Public O pinion." In Threat Politics: N ew Perspec- 
tives on Security, Risk and Crisis Management, ed. Johan Eriksson (Aldershot: Ashgate, 2001).

36. "For the analyst, the referent object of security became the state. In this world, security came from being a citizen, and insecurity from citizens of other states." Nana K. Poku, N eil Renwick, and John Glenn, op. cit., 12. On the conceptualization of security for the individuals qua persons and not qua citizens, see K. Krause and M. Williams, eds., Critical Security Studies: Concepts and Cases (London: U CL Press, 1997).

37. SeeRachel N eild, "From National Security to Citizen Security: Civil Society and theEvolution of Public Order Debates." Web page, 1999, Democratic Development Publications (refers to the first part, which is written by Warren Allmand); online: $<$ http://www.ichrdd.ca/english/commdoc/publications/de mD ev/d emD evPub.html.paper > (date accessed: 16 February 2002).

38. Colin J. Harvey, "Refugees, Rights and Human Security," Refuge 19, no. 4 (2001): 94-99: 95.

39. Ibid., 96 .

40. Interview with Ruud Lubbers, High Commissioner for Refugees, in Refugees Magazine. "Year in Review: Ruud Lubbers Reviews His First Year in Office (Interview)," Refugees M agazine, no. 125 (2001): 20.

41. Astri Suhrke, "Environmental Change, Migration, and Conflict: A Lethal Feedback Dynamic?" In M anaging Global Chaos: Sources of and Responses to International Conflicts, ed. Chester A. Crocker, Fen Osler Hampson, and Pamela Aall (Washington, D.C.: U nited States Institute of Peace Press, 1996).

42. Warren Zimmermann, "M igrants and Refugees: A Threat to Security?" In Threatened Peoples, Threatened Borders: W orld Migration and U.S. Policy, ed. Michael S. Teitelbaum and Myron Weiner (New York: The American Assembly, Columbia University, 1995): 107.

43. M yron Weiner, "Security, Stability and International Migration," International Security 17 (92-93): 91-126.

44. On societal security and insecurity, see Ole Waever, Barry Buzan, M orten Kelstrup, and Pierre Lemaitre, op. cit.

45. Reg Whitaker, "Refugees: The Security Dimension," Citizenship Studies 2, no. 3 (98): 413-434: 422.

46. For example: David T. Graham and Nana K. Poku, op. cit., looks at a range of security and human security issues related to the displacement of civilian populationsand shows how the tenuous existence of migrants can lead to a myriad of human security threats.

47. John G. Ruggie, Constructing the World Polity: Essays in International Institutionalization (London: Routledge, 1998).

48. Reg Whitaker, op. cit.

49. R B J Walker, "Security, Sovereignty, and the Challenge of World Politics," Alternatives 15 (90): 3-27.

50. Among these areincluded international bureaucracies such as the UN, as well as non-governmental organizations devoted to humanitarian causes. On the influence of non-state actors in the international system, see Thomas Risse, ed., Bringing Transnational Relations Back In: Non-State Actors, Domestic Structures and International Institutions. (Cambridge: Cam- bridge University Press, 1995); M argaret Keck and Kathryn Sikkink, Activists Beyond Borders: Advocacy N etworks in International Politics(Ithaca, N.Y.: Cornell U niversity Press, 1998); Karsten Ronit and Volker Schneider, eds., Private Organizations in Global Politics (New York: Routledge, 2000).

51. Hereunderstood as a construction of the international system where the individual is the holder of human rights and entitlements, and where “... the institutions involved in their implementation, both formal and informal or civic, proceed from the international to the national and local levels, rather than vice-versa as is the case with democracy." David Beetham, "Human Rights as a Model for Cosmopolitan Democracy." In Re-Imagining Political Community Studies in Cosmopolitan Democracy, ed. Daniele Archibugi, David Held, and M artin Koehler (Cambridge: Polity Press, 1998), 59-60. For a development of the characteristics of cosmopolitan positions, see T. W. Pogge, "'Cosmopolitanism and Sovereignty.'" In Political Restructuring in Europe Ethical Perspectives, ed. Chris Brown (London: Routledge, 1994).

52. This has been the case in several instances of UNHCR intervention in humanitarian emergencies, where the presence of the organization in the country of origin led to the "legitimization" of border closures. On therisk of such focus on human security leading to a lowering of the humanitarian goals and of the possible expectations for refugees regarding their life in exile, see Elisabeth Abiri, Elisabeth, op. cit., 73.

53. James N. Rosenau, Thinking Theory Thoroughly: Coherent Approaches to an Incoherent World (Boulder: Westview Press, 2000).

54. Paul B. Stares, The New Security Agenda: A Global Survey (Tokyo: Japan Center for International Exchange, 1998) : 12.

55. Colin J. Harvey, op. cit., 95.

56. Jan Egeland, Impotent Superpower - Potent Small State: Potentials and Limitations of $\mathrm{H}$ uman Rights $\mathrm{O}$ bjectives in the Foreign Policies of the United States and Norway (Oslo: Norwegian University Press, 1988).

57. For a list of NGOs and research centres divided by region, see Sarah Edsen, op. cit.

58. Ellen Lammers, op. cit.

59. Anna M. Florini and P.J. Simmons, op. cit.

60. Sarah Edsen, op. cit., 85.

61. David A. Baldwin, op. cit., 5.

62. Gavin Cawthra, op. cit.

63. Gavin Cawthra, op. cit.

64. OleWaever, op. cit.

65. Elisabeth Abiri, op. cit.

66. See Xavier Furtado, "Human Security and Asia's Financial Crisis. A Critique of Canadian Policy," International Journal LV, no. 3 (2000): 355-75; and Kanti Bajpai, op. cit.

67. Refugees M agazine, op. cit., 6.

68. Aristide Zolberg, "Guarding the Gates in a World on the Move," Social Science Research Council Essays, online: <http://www.ssrc.org/sept11/essays/zolberg.htm> (accessed 25 April 2002); H uman Rights Watch., "W orld Report 2002," Human Rights Watch web page, online: <http://hrw.org/ 
wr2k2/refugees.html \#Refugee Protection Post September 11> (accessed 25 April 2002).

69. See August Gribbin, "Security Leaves Refugees Stranded," Washington Times, 2002.

70. Human Rights Watch, op. cit.

71. Statewatch, "Statewatch N ews Online: Bush Demands for EU Cooperation on Justice and Home Affairs," online: <http://www.statewatch.org/news/2001/nov/06uslet.htm.> (date accessed: A pril 25, 2002).

72. Kanishka Jayasuriya, "9/11 and the New 'Anti-politics' of "Security," Social Science Research Council Essays, online: $<$ <ttp://www.ssrc.org/sept11/essays/jayasuriya.htm> (date accessed: A pril 25, 2002).

73. Ibid.

74. Ibid.

75. Reg Whitaker, op. cit.

76. See Sharryn J. Aiken, "M anufacturing 'Terrorists': Refugees, National Security, and Canadian Law (Part 1)," Refuge 19, no. 3 (2001): 54-73; David J. Whittaker, ed. The Terrorism Reader (London: Routledge, 2001); see also Amnesty International, Rights at Risk: Amnesty International's Concerns regarding Security Legislation and Law Enforcement M easures, AI Index: ACT 30/001/2002, 2002.

77. Didier Bigo, "To Reassure, and Protect, after September 11," Social Science Research Council Essays, online: <http://www.ssrc.org/sept11/essays/bigo.htm> (date accessed: 25 April 2002); al so Amnesty International, op. cit., and the fear that the fight against terrorism may be used to justify repression and undermine the institution of asylum.

78. Human Rights Watch, op. cit.

79. See, for instance, European Commission document COM (2001) 743, 5 Dec. 2001; see also Framework Decision on combating terrorism agreed by the $\mathrm{H} \mathrm{A}$ Council on $6 \mathrm{Decem}$ ber 2001 and 27 December 2001 - Council "Common Position on Combating Terrorism."

80. Human Rights Watch, op. cit.

81. Kanishka Jayasuriya, op. cit.

82. Reg Whitaker, op. cit.

83. See for example Council of the European Union, Strategic Committee on Immigration, Frontiers and Asylum: M eeting With the U nited States, 26.10.01, 2001.

84. The Center for Democracy and Technology, "Groups Call for Liberty and Security in September 11th Aftermath," available online: <http://www.cdt.org/security/011101liberty.shtml.> (date accessed: 25 A pril 2002).

83. Warren Zimmermann, op. cit.

84. Reg Whitaker, op. cit.

85. See J effrey Ayres and Sidney Tarrow, "The Shifting Grounds for Transnational Civic Action," Social Science Research Council Essays, online: <http://www.ssrc.org/sept11/essays/ ayres.htm> (date accessed: 25 A pril 2002); and “M y own view is that scholars of refugee law need to engage with work in deliberative democracy in order to sketch an approach that would present a real challenge to the current practices of states," Colin J. Harvey, op. cit., 96.
Raquel Freitas is a Ph.D. candidate in the Department of Social and Political Sciences at the European U niversi ty Institute (Florence), developing research on the role and mandate of the United Nations High Commissioner for Refugees (UNHCR) in the present international system. 